\title{
Appendix: Additional Readings
}

Abroms, K. I., \& Hodera, T. L. (1979). Acceptance hierarchy of handicaps: Validation of Kirk's statement "Special education often begins where medicine stops." Journal of Learning Disabilities, 12, 15-20. doi:10.1177/002221947901200104

Achenbaum, W. A. (2009). A history of productive aging and the boomers. In R. B. Hudson (Ed.), Boomer or bust? Economic and political issues of the graying society (pp. 47-109). Westport, CT: Praeger.

Addison, J. T. (1992). Urie Bronfenbrenner. Human Ecology, 20(2), 16-20.

Alwin, D. F., \& McCammon, R. J. (2004). Generations, cohorts, and social change. In J. T. Mortimer \& M. J. Shanahan (Eds.), Handbook of the life course (pp. 23-49). New York, NY: Springer Publishing Company.

Ambron, S. R., \& Brodzinsky, D. (1979). Lifespan human development. New York, NY: Holt, Rinehart \& Winston.

Antonak, R. F. (1980). A hierarchy of attitudes toward exceptionality. The Journal of Special Education, 14, 231-241. doi:10.1177/002246698001400210

Arnett, J. J. (1992). Reckless behavior in adolescence: A developmental perspective. Developmental Review, 12, 339-373. doi:10.1016/0273-2297(92)90013-R

Azar, B. (1997, October). Was Freud right: Maybe, maybe not. Monitor of the American Psychological Association. Washington, DC: American Psychological Association.

Ball, S. A. (2004). Personality traits, disorders, and substance abuse. In R. M. Stelmack (Ed.), On the psychobiology of personality (pp. 203-221). Amsterdam, The Netherlands: Elsevier.

Baltes, M. M., \& Carstensen, L. L. (1996). The process of successful ageing. Aging and Society, 16, 397-422. doi:10.1017/S0144686X00003603

Batshaw, M. L., Pellegrino, L., \& Roizen, N. J. (Eds.). (2007). Children with disabilities (6th ed.). Baltimore, MD: Paul H. Brookes.

Becker, G., \& Kaufman, S. (1988). Old age, rehabilitation, and research: A review of the issues. The Gerontologist, 28, 459-468. doi:10.1093/geront/28.4.459

Bengston, V. L. (2001). Beyond the nuclear family: The increasing importance of multigenerational bonds. Journal of Marriage and the Family, 63, 1-16. doi:10.1111/j.1741-3737.2001.00001.x

Bernbaum, J. C., \& Batshaw, M. L. (1998). Born too soon, born too small. In M. L. Batshaw (Ed.), Children with disabilities (4th ed., pp. 115-139). Baltimore, MD: Paul H. Brookes.

Bernstein, N. R. (1976). Emotional care of the facially burned and disfigured. Boston, MA: Little, Brown.

Bishop, C. (2009). The looming economic of boomer health care. In R. B. Hudson (Ed.), Boomer bust? Economic and political issues of the graying society (pp. 95-109). Westport, CT: Praeger.

Blackburn, J. (1988). Chronic health problems of the elderly. In C. S. Chilman, E. W. Nunnally, \& F. M. Cox (Eds.), Chronic illness and disability: Families in trouble (pp. 108-122). Newbury Park, CA: Sage. 
Bowbly, J. (1958). The nature of the child's tie to his mother. International Journal of Psycho-Analysis, 39, 350-373.

Brandist, C. (2006). The rise of Soviet sociolinguistics from the ashes of Völkerpsychologie. Journal of the History of the Behavioral Sciences, 42, 261-277. doi:10.1002/jhbs.20172

Britell, C. W., \& Hammond, M. C. (1994). Spinal cord injury. In R. M. Hayes, G. H. Kraft, \& W. C. Stolov (Eds.), Chronic disease and disability: A contemporary approach to medical practice (pp. 142-160). New York, NY: Demos Medical Publishing

Brookes, T. (1995). Catching my breath: An asthmatic explores his illness. New York, NY: Vintage.

Brooks, D. (2011, January 17). Annals of psychology: Social animal. The New Yorker, pp. 26-32.

Bruce, S., \& Muhammad, Z. (2009). The development of object permanence in children with intellectual disability, physical disability, autism, and blindness. International Journal of Disability, 56(3), 229-246. doi:10.1080/10349120903102213

Byrd, E. K., \& Elliott, T. R. (1985). Feature films and disability: A descriptive study. Rehabilitation Psychology, 30, 47-51. doi:10.1037/h0091014

Byrom, B. (2004). A pupil and a patient. Hospitals-schools in progressive America. In S. Danforth \& S. D. Taff (Eds.), Crucial readings in special education (pp. 25-37). Upper Saddle River, NJ: Pearson.

Carr, D. (Ed.). (2009). Encyclopedia of the life course and human development. Vol. 3: Later life. Detroit, MI: Gale Cengage Learning.

Carroll, T. J. (1961). Blindness: What it is, what it does, and how to live with it. Boston, MA: Little, Brown.

Case-Smith, J. (2004). Parenting a child with a chronic medical condition. American Journal of Occupational Theory, 58, 551-560. doi:10.5014/ajot.58.5.551

Cataldo, M. F., Kahng, S. W., DeLeon, I. G., Martens, B. K., Friman, P. C., \& Cataldo, M. (2005). Behavioral principles, assessment, and therapy. In M. L. Batshaw, L. Pellegrino, \& N. J. Roizen (Eds.), Children with disabilities (6th ed., pp. 539-555). Baltimore, MD: Paul H. Brookes.

Centers for Disease Control and Prevention. (2007). Fetal alcohol spectrum disorders. Retrieved from https://www.cdc.gov/ncbddd/fasd/index.html

Chang, R., \& Page, R. C. (1991). Characteristics of the self-actualized persons: Visions from the East and West. Counseling and Values, 36, 2-10. doi:10.1002/j.2161-007X.1991. tb00772.x

Colby, A., Kolberg, L., Gibbs, J. C., Kandee, D., Hewer, R., Kaufman, K., ... Speicher-Dubin, B. (1983). Assessing moral stages: A manual. New York, NY: Cambridge University Press.

Cole, M., \& Gajdamaschko, N. (2007). Vygotsky and culture. In J. W. Daniels \& M. Cole (Eds.), The Cambridge companion to Vygotsky. New York, NY: Cambridge University Press.

Coles, R. (1970). Erik H. Erikson: The growth of his work. Boston, MA: Little, Brown.

Conway, C. M., Pisoni, D. B., Anaya, E. M., Karpicke, J., \& Henning, S. C. (2011). Implicit sequence learning in deaf children with cochlear implants. Developmental Science, 14, 69-82. doi:10.1111/j.1467-7687.2010.00960.x

Cott, C., \& Wilkins, S. (1993). Aging, chronic illness, and disability. In M. Nagler (Ed.), Perspectives on disability (2nd ed., pp. 363-377). Palo Alto, CA: Health Markets Research.

Crain, W. C. (1985). Theories of development. New York, NY: Prentice-Hall.

Daniels, H. (2007). Pedagogy. In J. W. Daniels \& M. Cole (Eds.), The Cambridge companion to Vygotsky. New York, NY: Cambridge University Press.

Datan, N., Greene, A. L., \& Reese, H. W. (Eds.). (1986). Life-span developmental psychology: Intergenerational relations. Hillsdale, NJ: Lawrence Erlbaum.

Davis, L. J. (1997). Constructing normalcy: The bell curve, the novel, and the invention of the disabled body in the nineteenth century. In L. J. Davis (Ed.), Disability studies reader (pp. 307-314). New York, NY: Routledge. 
Deegan, P. E. (1997). Recovery: the lived experience of rehabilitation. In L. Spaniol, C. Gagne, \& M. Koehler (Eds.), Psychological and social aspects of psychiatric disability (pp. 92-98). Boston, MA: Boston University, Center for Psychiatric Rehabilitation.

Demo, D. H. (1992). The self-concept over time: Research issues and directions. Annual Review of Sociology, 18, 303-336. doi:10.1146/annurev.soc.18.1.303

DeNavas-Walt, C., \& Proctor, B. D. (2014). Income, poverty, and health insurance coverage in the United States 2014. Davis, CA: University of California. Retrieved from https:// poverty.ucdavis.edu/faq/how-poverty-status-related-disability

DePoy, E., \& Gibson, S. F. (2010). Studying disability: Multiple theories and responses. Thousand Oaks, CA: Sage.

Dinsmoor, J. A. (1992). Setting the record straight: The social views of B. F. Skinner. American Psychologist, 47, 1454-1463. doi:10.1037//0003-066x.47.11.1454

Donohew, L., Bardo, M. T., \& Zimmerman, R. S. (2004). Personality and risky behavior: Communication and prevention. In R. M. Stelmack (Ed.), On the psychobiology of personality (pp. 223-245). Amsterdam, The Netherlands: Elsevier.

Durand, V. M., \& Crimmins, D. B. (1988). Identifying the variables maintaining self-injurious behavior. Journal of Autism and Developmental Disorders, 18, 99-117. doi:10.1007/ bf02211821

Eldredge, G. M., Gerard, G., \& Smart, J. F. (1994). A distance education model for rehabilitation education. Rehabilitation Administration, 18, 75-79.

Elms, A. C. (1981). Skinner's dark year and Walden Two. American Psychologist, 36, 470-479. doi:10.1037/0003-066X.36.5.470

Erikson, E. H. (1970, December 21). The quest for identity. Newsweek, pp. 84-89.

Erikson, E. H. (1975). Life history and the historical moment. New York, NY: Norton.

Faull, K., Hills, M. D., Cochrane, G., Gray, J., Hunt, M., McKenzie, C., \& Winter, L. (2004). Investigation of health perspectives of those with physical disabilities: The role of spirituality as a determinant of health. Disability and Rehabilitation, 26, 129-144. doi:10.1080/09638280310001636419

Frankel, M. (1971). Personality as a response: Behaviorism. In S. R. Maddi (Ed.), Perspectives on personality. Boston, MA: Little, Brown.

Friedman, D., Holmbeck, G. N., DeLucia, C., Jandasek, B., \& Zebracki, K. (2009). Trajectories of autonomy development across the adolescent transition in children with spina bifida. Rehabilitation Psychology, 54, 16-27. doi:10.1037/a0014279

Friedman, L. J. (1999). Identity's architect: A biography of Erik H. Erikson. New York, NY: Schribner.

Galambos, C. M., \& Rosen, A. (2000). The aging are coming and they are us. In S. M. Kergher, A. E. Fortune, \& S. L. Witkin (Eds.), Aging and social work: The changing landscape (pp. 1-19). Washington, DC: NASW Press.

Gallotti, K. M., Kozberg, S. F., \& Farmer, M. C. (1991). Gender and developmental differences in adolescents' conceptions of moral reasoning. Journal of Youth and Adolescence, 20, 13-20. doi:10.1007/bf01537349

Garmon, L. C., Basinger, K. S., Gregg, V. R., \& Gibbs, J. C. (1996). Gender differences in stage and expression of moral judgment. Merrill-Palmer Quarterly, 42, 418-437.

Gay, P. (1988). Freud: A life for our time. New York, NY: Norton.

Gerber, P. J., \& Brown, D. S. (Eds.). (1997). Learning disabilities and employment. Austin, TX: Pro-Ed.

Gindis, B. (1995). The social/cultural implication of disability: Vygotsky's paradigm for special education. Educational Psychologist, 30(2), 77-81. doi:10.1207/s15326985ep3002_4

Glueckauf, R. L., \& Quittner, A. L. (1984). Facing physical disability as a young adult: Psychological issues and approaches. In M. G. Eisenberg, L. C. Sutkin, \& M. A. Jansen (Eds.), Chronic illness and disability through the life span: Effects on self and the family (pp. 167-183). New York, NY: Springer Publishing Company.

Gold, J. T. (1996). Growth hormone treatment of children with neural tube defects. Journal of Pediatrics, 129, 771. doi:10.1016/s0022-3476(96)70171-3 
Grealy, L. (1999). Pony party. In K. Fries (Ed.) Staring back: The disability experience from the inside out (pp. 14-21) New York, NY: Plume.

Hall, C. S., Lindzey, G., \& Campbell, J. B. (1998). Theories of personality (4th ed.). New York, NY: Wiley.

Hall, E. (1983, June). A conversation with Erik Erikson. Psychology Today, 17(6), 22, 24-30.

Hannah, M. E., \& Midlarsky, E. (1987). Differential impact of labels and behavioral descriptions on attitudes toward people with disabilities. Rehabilitation Psychology, 32, 227-238. doi:10.1037/h0091580

Hanson, K., Neuman, T., \& Voris, M. (2003). Understanding the health care needs and experiences of people with disabilities: Findings from a 2003 survey. Washington, DC: Kaiser Family Foundation.

Hardy, M. A. (2006). Older workers. In R. H. Binstock \& L. K. George (Eds.), Handbook of aging and the social sciences (6th ed., pp. 201-216). Boston, MA: Academic Press.

Harley, D. A., Greer, B. G., \& Hackerman, A. E. (1997). Substance abuse and rehabilitation. Rehabilitation Education, 11, 353-372.

Hayes, R. M., Kraft, G. H., \& Stolov, W. C. (Eds). (1994). Chronic disease and disability: A contemporary rehabilitation approach to medical practice. New York, NY: Demos Medical Publishing.

Hendry, C. N. (2000). Childhood disintegrative disorder: Should it be considered a distinct diagnosis? Clinical Psychology Review, 20, 77-90. doi:10.1016/S0272-7358(98)00094-4

Hersen, M., \& Van Hasselt, V. B. (Eds.). (1990). Psychological aspects of developmental and physical disabilities. Newbury Park, CA: Sage.

Heumann, J. E. (1979). Disability: Our challenge. New York, NY: Columbia University Press.

Higo, M., \& Williamson, J. B. (2009). Retirement. In D. Carr (Ed.), Encyclopedia of the life course and human development. Vol. 3: Later life (pp. 328-336). Detroit, MI: Gale Cengage Learning.

Hirandini, V. (2005). Rethinking disability in social work: Interdisciplinary perspectives. In G. E. May \& M. B. Raske (Eds.), Ending discrimination in social work: Strategies for social workers (pp. 71-81). Boston, MA: Allyn \& Bacon.

Holden, K. C. (2009). The Boomers and their economic prospects. In R. B. Hudson (Ed.), Boomer bust? Economic and political issues of the graying society (pp. 63-75). Westport, CT: Praeger.

Hoover, K. (Ed.). (2004). The future of identity: Centennial reflections on the legacy of Erik Erikson. New York, NY: Lexington Books.

Horowitz, F. D. (1987). Exploring developmental theories: Toward a structural/behavioral model of development. Hillsdale, NJ: Lawrence Erlbaum.

Hughes, M. E. (2009). Baby boom cohort. In D. Carr (Ed.), Encyclopedia of the life course and human development. Vol. 3: Later life. Detroit, MI: Gale Cengage Learning.

Hurst, R. (1998). Forget pity or charity: Disability is a rights issue. Disability International, 5(3), 14-16.

Ireys, H. T., \& Burr, C. K. (1984). Apart and a part: Family issues for young adults with chronic illness and disability. In M. G. Eisenberg, L. C. Sutkin, \& M. A. Jansen (Eds.), Chronic illness and disability through the life span: Effects on self and the family (pp. 184-206). New York, NY: Springer Publishing Company.

Ivey, A. E., \& Ivey, M. B. (1998). Reframing the DSM-IV: Positive strategies from developmental counseling and therapy. Journal of Counseling and Development, 76, 334-350. doi:10.1002/j.1556-6676.1998.tb02550.x

Jack, M. (1984). Verbal behavior. Journal of the Experimental Analysis of Behavior, 42, 363-376. doi:10.1901/jeab.1984.42-363

Jahoda, A., Dagnan, D., Kroese, B. S., Pert, C., \& Trower, P. (2009). Cognitive behavioral therapy: From face to face interaction to a broader contextual 
understanding of change. Journal of Intellectual Disability Research, 53(9), 759-771. doi:10.1111/j.1365-2788.2009.01189.x

Jason, L. A., Jordan, K. M., Richman, J. A., Rademaker, A. W., Huang, C., McCready, W., \& Frankenberry, E. L. (1999). A community-based study of prolonged and chronic fatigue. Journal of Health Psychology, 4, 9-26. doi:10.1177/135910539900400103

Jason, L. A., Porter, N., Hunnell, J., Brown, A., Rademaker, A., \& Richman, J. A. (2011). A natural history study of chronic fatigue syndrome. Rehabilitation Psychology, 56, 32-42. doi:10.1037/a0022595

Johnson, S. K. (2008). Medically unexplained illness: Gender and biopsychosocial implications. Washington, DC: American Psychological Association.

Jones, E. (1957). The life and work of Sigmund Freud (Vol. 3). New York, NY: Basic Books. Juengst, E. T. (2005). Can aging be interpreted as a healthy, positive process? In M. Wykle, P. J. Whitehouse, \& D. L. Morris (Eds.), Successful aging throughout the lifespan (pp. 3-18). New York, NY: Springer Publishing Company.

Jungers, C.M.(2010).Leaving home: An examination of late-life relocation among older adults. Journal of Counseling and Development, 88, 416-423. doi:10.1002/j.1556-6678.2010. tb00041.x

Katznelson, I. (2005). When affirmative action was white. New York, NY: Norton.

Keeter, S., \& Taylor, P. (2009, December 11). The millennials. Washington, DC: Pew Research Center.

Keller, H. (1990). The story of my life. New York, NY: Bantam.

Keller, M. (2006). The development of obligations and responsibilities in cultural context. In L. Smith \& J. Voneche (Eds.), Norms in human development (pp. 168-188). Cambridge, UK: Cambridge University Press.

Kiesler, D. J. (1999). Beyond the disease model of mental disorders. Westport, CT: Praeger.

Klein, N. K., \& Safford, P. L. (2001). Application of Piaget's theory to the study of thinking of the mentally retarded: A review of research. The Journal of Special Education, 11(2), 201-216. doi:10.1177/002246697701100211

Klobas, L. (1988). Disability drama in television and film. Jefferson, NC: McFarlan.

Kohlberg, L. (1973). Continuities in childhood and adult moral development revisited. In P. Baltes \& K. W. Schaie (Eds.), Lifespan developmental psychology: Personality and socialization (pp. 180-204). New York, NY: Academic Press.

Kohlberg, L. (1976). Moral stages and moralization: The cognitive-development approach. In T. Likona (Ed.), Moral development and behavior: Theory, research, and social issues (pp. 31-53). New York, NY: Holt, Rinehart, \& Winston.

Kohlberg, L. (1981). Essays on moral development. San Francisco, CA: Harper \& Row.

Kohlberg, L. (1984). The psychology of moral development: The nature and validity of moral stages. San Francisco, CA: Harper \& Row.

Kohlberg, L. (1987). Child psychology and childhood education: A cognitive developmental view. New York, NY: Longman.

Kohlberg, L., \& Gilligan, C. (1971, Fall). The adolescent as a philosopher: The discovery of self in a postconventional world (Vol. 100, pp. 1051-1086). Boston, MA: Daedalus.

Kriegel, L. (1953). The long walk home. New York, NY: Appleton-Century.

Kuh, D., \& Ben-Shlomo, Y. (Eds.). (2004). A life course approach to chronic disease epidemiology (2nd ed.). Oxford, UK: Oxford University Press.

Languis, M., \& Wilcox, J. (1981). A life-span human development model of learning for early education. Theory into Practice, 20, 79-85. doi:10.1080/00405848109542933

Lareau, A., \& Conley, D. (Eds.). (2008). Social class: How does it work? New York, NY: Sage.

Lawton, M. P. (1996). The aging family in a multigenerational perspective. In G. H. S. Singer, L. E. Powers, \& A. L. Olson (Eds.), Redefining family support: Innovations in public private partnerships (pp. 135-149). Baltimore, MD: Paul H. Brookes. 
Lewis, B. (2010). A mad fight: Psychiatry and disability activism. In L. J. Davis (Ed.), The disability studies reader (3rd ed.). New York, NY: Routledge.

Li, S. C., Lindenberger, U., Hommel, B., Aschersleben, G., Prinz, W., \& Baltes, P. B. (2004). Transformations in the couplings among intellectual abilities and constituent cognitive processes across the life span. Psychological Science, 15, 155-163. doi:10.1111/j.0956-7976.2004.01503003.x

Liachowitz, C. H. (1988) Disability as a social construct: Legislative roots. Philadelphia, PA: University of Pennsylvania Press.

Light, E., \& Lebowitz, B. D. (Eds.). (1991). The elderly with chronic mental illness. New York, NY: Springer Publishing Company

Livneh, H. (1991). On the origins of negative attitudes toward people with disabilities. In R. P. Marinelli \& A. E. Dell Orto (Eds.), The psychological and social impact of disability (3rd ed., pp. 181-196). New York, NY: Springer Publishing Company.

Livneh, H., \& Cook, D. (2005). Psychosocial impact of disability. In R. M. Parker, E. M. Szymanski, \& J. B. Patterson (Eds.), Rehabilitation counseling: Basics and beyond (4th ed., pp. 187-224). Austin, TX: Pro-Ed.

Luria, A. R. (1976). Cognitive development: Its cultural and social foundations. Cambridge, MA: Harvard University Press.

Luria, A. R. (1981). Language and cognition. New York, NY: Wiley.

Maddi, S. R. (1996). Personality theories (6th ed.). Pacific Grove, CA: Brooks/Cole.

Maples, M. F., \& Abney, P. C. (2006). Baby boomers mature and gerontological counseling comes of age. Journal of Counseling and Development, 84, 3-9. doi:10.1002/j.1556-6678.2006.tb00374.x

Marrero, D. G., \& Guare, J. C. (2005). Diabetes mellitus. In H. H. Zarestksy, E. F. Richter, \& M. G. Eisenberg (Eds.), Medical aspects of disability: A handbook for the rehabilitation professional (3rd ed., pp. 241-265). New York, NY: Springer Publishing Company.

Maslow, A. H. (1968). Toward a psychology of being (2nd ed.). Princeton, NJ: Van Nostrand.

Maslow, A. H. (1971). The further reaches of human nature. New York, NY: Viking.

McAdams, D. P., de St. Aubin, E., \& Logan, R. L. (1993). Generativity among young, midlife, and older adults. Psychology and Aging, 8, 221-230. doi:10.1037/0882-7974.8.2.221

McMahon, B. T., Shaw, L. R., \& Jaet, D. N. (1995). An empirical analysis: Employment and disability from an ADA litigation perspective. NARPPS Journal, 10(1), 3-14.

Mettler, S. (2005). Soldiers to citizen: The G.I. bill and the making of the greatest generation. New York, NY: Oxford University Press.

Miller, S., \& Morgan, M. (1980). Marriage matters: For people with disabilities, too. Sexuality and Disability, 3, 203-211. doi:10.1007/BF01100757

Moen, P. (1996). Gender, age, and the lifecourse. In R. H. Binstock \& L. K. George (Eds.), Handbook of aging and the social sciences (pp. 171-187). San Diego, CA: Academic Press.

Mueller, A. S. (2009). Body image, childhood, and adolescence. In D. Carr (Ed.), Encyclopedia of the life course and human development (Vol. 1, pp. 58-62). New York, NY: Macmillan.

Mukulincer, M., \& Florian, V. (1998). The relationship between adult attachment styles and emotional and cognitive reactions to stressful situations. In J. A. Simpson \& W. S. Rholes (Eds.), Attachment theory and close relationships (pp. 143-165). New York, NY: Guilford.

Murphy, C., \& Barnes-Holmes, D. (2009). Establishing derived manding for specific amounts with three children: An attempt at synthesizing Skinner's verbal behavior with relational frame theory. The Psychological Record, 59, 75-92. doi:10.1007/BF03395650

Mutchler, J. E., \& Burr, J. (2009). Boomer diversity and well-being: Race, ethnicity, and gender. In R. B. Hudson (Ed.), Boomer bust? Economic and political issues of the graying society (pp. 23-45). Westport, CT: Praeger.

National Public Radio. (1998, May). Disability history project. What's work got to do with it? Retrieved from https://www.npr.org/programs/disability/project.dir/project.html 
Ng, T. W. H., Sorensen, K. L., \& Eby, L. T. (2006). Locus of control at work: A meta-analysis. Journal of Organizational Behavior, 27, 1057-1087. doi:10.1002/job.416

Nielsen, K. E. (2006). Was Helen Keller deaf? Blindness, deafness, and multiple identities. In B. J. Brueggemann, \& S. Burch (Eds.), Women and deafness: Double visions (pp. 21-39). Washington, DC: Gallaudet University.

Nordqvist, I. (1980). Sexual counseling for disabled persons. Sexuality and Disability, 3, 193-198. doi:10.1007/BF01100755

O'Brien, M. (1997, January). Maybe you'd rather die than be me. Disability in Action Activist, p. 3.

Ochse, R., \& Plug, C. (1986). Cross cultural investigation of the validity of Erikson's theory of personality development. Journal of Personality and Social Psychology, 50, 12401252. doi:10.1037/0022-3514.50.6.1240

O’Day, B., \& Goldstein, M. (2005). Advocacy issues and strategies for the 21st century: Key informant interviews. Journal of Disability Policy Issues, 15, 240-250. doi:10.1177/10442073050150040601

O’Neill, G. (2009). The baby boom age wave: Population success or tsunami? In R. B. Hudson (Ed.), Boomer bust? Economic and political issues of the graying society (pp. 3-22). Westport, CT: Praeger.

Oser, F., \& Reichenbach, R. (2005). Moral resilience-The unhappy moralist. In W. Edelstein \& G. Nunner-Winkler (Eds.), Advances in Psychology: Vol. 137. Morality in context (pp. 203-224). Amsterdam, The Netherlands: Elsevier.

Paris, J. (2000). Myths of childhood. Philadelphia, PA: Taylor \& Francis.

Parisi, T. (1987). Why Freud failed: Some implications for neurophysiology and sociobiology. American Psychologist, 42, 235-242. doi:10.1037/0003-066X.42.3.235

Perrone, K. M., Gordon, P. A., \& Tschopp, M. K. (2006). Caregiver marital satisfaction when a spouse has multiple sclerosis. Journal of Applied Rehabilitation Counseling, 37, 26-32. doi:10.1891/0047-2220.37.2.26

Pervin, L. A., \& John, O. P. (2001). Personality: Theory and research (8th ed.). New York, NY: John Wiley.

Piaget, J. (1952). The language and thought of the child. London, UK: Routledge.

Piaget, J. (1954). The construction of reality in the child. New York, NY: Basic Books.

Piaget, J. (1962). Play, dreams, and imitation in childhood. New York, NY: Norton.

Piaget, J. (1965). The moral judgment of the child. New York, NY: Free Press.

Pimpare, S. (2009). The failures of American poverty measures. Journal of Sociology and Social Welfare, 36, 103-122.

Plutchik, R. (1980). A general psycho evolutionary theory of emotion. In R. Plutchik \& H. Kellerman (Eds.), Theory, research, and experience (pp. 3-33). New York, NY: Academic.

Reed, P. G. (1991). Toward a nursing theory of self-transcendence: Deductive reformulation using developmental theories. Advances in Nursing Science, 13(4), 64-77. doi:10.1097/00012272-199106000-00008

Rix, S. E. (2009). Will the boomers revolutionize work and retirement? In R. B. Hudson (Ed.), Boomer bust? Economic and political issues of the graying society (pp. 77-93). Westport, CT: Praeger.

Robb, C., Chen, H., \& Haley, W. E. (2002). Ageism in mental health and health care: A critical review. Journal of Clinical Geropsychology, 8, 1-12. doi:10.1023/A:1013013322947

Robinson, I. (1988). Managing symptoms in chronic disease: Some dimensions of patients' experience. International Disability Studies, 10(3), 112-119. doi:10.3109/09638288809164127

Rodger, S., \& Tooth, L. (2004). Adult siblings' perceptions of family life and loss: A pilot case study. Journal of Developmental and Physical Disabilities, 16, 53-71. doi:10.1023/B:JODD.0000010039.14986.41

Rogers, C. R. (1951). Client-centered therapy: Its current practice, implications, and theory. Boston, MA: Houghton Mifflin. 
Rogers, C. R. (1961). On becoming a person. Boston, MA: Houghton Mifflin.

Rogers, C. R. (1980). A way of being. Boston, MA: Houghton Mifflin.

Rolland, J. (1987). Chronic illness and the life cycle: A conceptual framework. Family Process, 26, 203-221. doi:10.1111/j.1545-5300.1987.00203.x

Rolland, J. S. (1988). A conceptual model of chronic and life threatening illness and its impact on family. In C. S. Chilman, E. W. Nunnally, \& F. M. Cox (Eds.), Chronic illness and disability: Families in trouble (pp. 17-68). Newbury Park, CA: Sage.

Rooehlkepartian, E. C., King, P. E., Wagener, L., \& Benson, P. L. (Eds.). (2005). The handbook of spiritual development in childhood and adolescence. Thousand Oaks, CA: Sage.

Rosenthal, T., \& Bandura, A. (1978). Psychological modeling: Theory and practice. In S. L. Garfield \& A. E. Bergin (Eds.), Handbook of psychotherapy and behavior change (pp. 621-658). New York, NY: Wiley.

Rousso, H. (1981). Disabled people are sexual, too. The Exceptional Parent, 11, 21-25.

Rustad, L. C. (1984). Family adjustment to chronic illness and disability in mid-life. In M. G. Eisenberg, L. C. Sutkin, \& M. A. Jansen (Eds.), Chronic illness and disability through the life span: Effects on self and the family (pp. 222-242). New York, NY: Springer Publishing Company.

Rutter, M. L. (1989). Pathways from childhood to adult life. Journal of Child Psychology and Psychiatry, 30, 23-51. doi:10.1111/j.1469-7610.1989.tb00768.x

Ryan, M. K., David, B., \& Reynolds, K. J. (2004). Who cares? The effect of gender and context on the self and moral reasoning. Psychology of Women Quarterly, 28, 246-255. doi:10.1111/j.1471-6402.2004.00142.x

Ryder, N. B. (1965). The cohort as a concept in the study of social change. American Sociological Review, 30, 843-861. doi:10.2307/2090964

Sautter, R. A., \& LeBlanc, L. A. (2006). Empirical applications of Skinner's analysis of verbal behavior with humans. Analysis of Verbal Behavior, 22, 35-48. doi:10.1007/ BF03393025

Schaie, K. W. (2007). Generational differences: The age-cohort period model. In J. E. Birren (Ed.), Encyclopedia of gerontology (2nd ed.), Oxford, UK: Elsevier.

Scheer, J., \& Groce, N. (1988). Impairment as human constant: Cross-cultural and historical perspectives on variation. Journal of Social Issues, 44, 23-37. doi:10.1111/j.1540-4560.1988.tb02046.x

Seifert, K. (1999). Constructing a psychology of teaching and learning. Boston, MA: Houghton Mifflin.

Shanahan, M. J., Hofer, S. M., \& Shanahan, L. (2004). Biological models of behavior and the life course. In J. T. Mortimer \& M. J. Shanahan (Eds.), Handbook of the life course (pp. 597-622). New York, NY: Springer Publishing Company.

Shontz, F. C. (1991). Six principles relating to disability and psychological adjustment. In R. P. Marinelli \& A. E. Dell Orto (Eds.), The psychological and social impact of disability (3rd ed., pp. 107-110). New York, NY: Springer Publishing Company.

Skinner, B. (1987). A humanist's alternative to A. A.'s Twelve Steps. Humanist, 47(4), 5. Retrieved from Academic Search Premier database.

Skinner, B. F. (1948). Walden two. New York, NY: Macmillan.

Skinner, B. F. (1953). Science and human behavior. New York, NY: Macmillan.

Skinner, B. F. (1971). Beyond freedom and dignity. New York, NY: Knopf.

Skinner, B. F. (1979). The shaping of a behaviorist. New York, NY: Knopf.

Smart, D. W., \& Smart, J. F. (1996). Scholarship reconsidered: A direction for rehabilitation. Rehabilitation Education, 10, 35-46.

Smart, J. F. (1993). Level of acculturation of Mexican Americans with disabilities and acceptance of disabilities. Rehabilitation Counseling Bulletin, 36, 199-211.

Smart, J. F. (1998). Multicultural rehabilitation education: Issues of implementation. Rehabilitation Education, 12, 167-173. 
Smart, J. F. (2014). Counseling individuals with physical, cognitive, and psychiatric disabilities. In C. C. Lee (Ed.), Multicultural counseling: New approaches to diversity (4th ed.). Washington, DC: American Counseling Association.

Smart, J. F., \& Smart, D. W. (1991). Acceptance of disability and the Mexican American culture. Rehabilitation Counseling Bulletin, 34, 356-367.

Smart, J. F., \& Smart, D. W. (1992). Cultural issues in the rehabilitation of Hispanics. Journal of Rehabilitation, 58, 29-37.

Smart, J. F., \& Smart, D. W. (1993a). Acculturation, biculturalism, and the rehabilitation of Mexican Americans. Journal of Applied Rehabilitation Counseling, 24, 46-51. doi:10.1891/0047-2220.24.2.46

Smart, J. F., \& Smart, D. W. (1993b). The rehabilitation of Hispanics with disabilities: Sociocultural constraints. Rehabilitation Education, 7, 167-184.

Smart, J. F., \& Smart, D. W. (1993c). Vocational evaluation of Hispanics with disabilities: Issues and implications. Vocational Evaluation and Work Adjustment Bulletin, 26, 111-121.

Smart, J. F., \& Smart, D. W. (1994a). Rehabilitation of Hispanics: Implications for training and education. Rehabilitation Education, 8, 360-369.

Smart, J. F., \& Smart, D. W. (1994b). The rehabilitation of Hispanics experiencing acculturative stress: Implications for practice. The Journal of Rehabilitation, 60(4), 8-12.

Smart, J. F., \& Smart, D. W. (1995a). Acculturative stress of Hispanics: Loss and challenge. Journal of Counseling and Development, 73, 390-396. doi:10.1002/j.1556-6676.1995. tb01770.x

Smart, J. F., \& Smart, D. W. (1995b). Acculturative stress: The experience of the Hispanic immigrant. The Counseling Psychologist, 23, 25-42. doi:10.1177/0011000095231003

Smart, J. F., \& Smart, D. W. (1995c). Issues in vocational evaluation of Hispanics with disabilities. In D. Crawford, F. Curnutt, D. I. Eargle, P. Leung, K. Robinson, \& S. Sabelli (Eds.), Directions in rehabilitation counseling. New York, NY: Harleigh.

Smart, J. F., \& Smart, D. W. (1995d). Response to Leal-Idrogo's "Further thoughts". Journal of Rehabilitation, 61, 24-25.

Smart, J. F., \& Smart, D. W. (1995e). The use of translators/interpreters in rehabilitation. Journal of Rehabilitation, 61, 14-20.

Smart, J. F., \& Smart, D. W. (1996). The rehabilitation of Hispanics: Topics of interest to educators. Rehabilitation Education, 10, 171-184.

Smart, J. F., \& Smart, D. W. (1997a). Introduction. In The Hatherleigh guide to vocational career counseling (pp. xi-xvii). New York, NY: Hatherleigh.

Smart, J. F., \& Smart, D. W. (1997b). The racial/ethnic demography of disability. Journal of Rehabilitation, 63, 9-15.

Smart, J. F., \& Smart, D. W. (2006). Models of disability: Implications for the counseling profession. Journal of Counseling and Development, 84,29-40. doi:10.1002/j.1556-6678.2006. tb00377.x

Smart, J. F., Smart, D. W., \& Eldredge, G. M. (1992). A review of the literature of Mexican Americans in public vocational rehabilitation programs. Rehabilitation Education, 6, 21-32.

Smart, J. F., Smart, D. W., \& Eldredge, G. M. (1993). A proposal for an undergraduate general education course on disability issues. Rehabilitation Education, 7, 109-117.

Smith, P. K., \& Hart, C. H. (2002). Blackwell handbook of childhood social development. Oxford, UK: Blackwell.

Smith, S. M., \& Kampfe, C. M. (1997). Interpersonal relationship implications of hearing loss in persons who are older. Journal of Rehabilitation, 63, 15-20.

Snarey, J. R., \& Keljo, K. (1991). In a gemeinschaft voice: The cross-cultural expansion of moral development model. In W. M. Kurtines \& J. L. Gewirtz (Eds.), Handbook of moral behavior and development (Vol. 1, pp. 395-424). Hillsdale, NJ: Erlbaum. 
Sobsey, D., \& Mansell, S. (1993). The prevention of sexual abuse of people with developmental disabilities. In M. Nagler (Ed.), Perspectives on disability (2nd ed., pp. 283-292). Palo Alto, CA: Health Markets Research.

Souter, S. (1993, August 16). Women with disabilities: How to become a boat rocker in life. Speech given at Ethics in Rehabilitation Conference. New Zealand Rehabilitation Association, Dunedin, New Zealand.

Stalcup, B. (Ed.). (1991). The disabled, current controversies series. San Diego, CA: Greenhaven.

Steenbarger, B. N. (2001). Placing our counseling texts in context: A reply to Lyddon. Journal of Counseling and Development, 73, 570-571. doi:10.1002/j.1556-6676.1995. tb01797.x

Strachey, J. (Ed.). (1964). The standard edition of the complete psychological works of Sigmund Freud. London, UK: Hogarth.

Strauss, A., \& Glaser, B. (1975). Chronic illness and the quality of life. St. Louis, MO: Mosby.

Symer, M. A., \& Qualls, S. A. (1999). Aging and mental health. Malden, MA: Blackwell.

Takahashi, K. (2005). Toward a life span theory of close relationships: The affective relationships model. Human Development, 48, 48-66. doi:10.1159/000083215

Thompson, G. (2005). Healthy and successful ageing. In G. Grand, P. Goward, M. Richardson, \& P. Ramcharan (Eds.) Learning disability: A life cycle approach to valuing people. New York, NY: Open University Press.

Tichy, M., Johnson, D. W., Johnson, R. T., \& Roseth, C. J. (2010). The impact of constructive controversy on moral development. Journal of Applied Social Psychology, 40, 765-787. doi:10.1111/j.1559-1816.2010.00597.x

Trieschmann, R. B. (1987). Aging with a disability. New York, NY: Demos Medical Publishing.

Tudge, J., \& Rogoff, B. (1999). Peer influences on cognitive development: Piagetian and Vygotskian perspectives. In P. Lloyd \& C. Fernyhough (Eds.), Lev Vygotsky critical assessments. New York, NY: Routledge.

Turkeltaub, P. E., Garaeau, L., Flowers, D. L. Zeffiro, T. A., \& Eden, G. F. (2003). Development of neural mechanisms for reading. Nature Neuroscience, 6, 767-773. doi:10.1038/nn1065

Verbrugge, L. M., \& Yang, L. (2000). Aging with disability and disability with aging. Journal of Disability Policy Studies, 12, 253-267. doi:10.1177/104420730201200405

Vilchinsky, N., Findler, L., \& Werner, S. (2010). Attitudes toward people with disabilities: The perspective of attachment theory. Rehabilitation Psychology, 55, 298-306. doi:10.1037/a0020491

Vygotsky, L. A. (1962). Thought and language. Cambridge, MA: Massachusetts Institute of Technology.

Vygotsky, L. S. (1978). Interaction between learning and development. In M. Cole, V. John-Steiner, S. Scribner, \& E. Souberman (Eds.), Mind in society: The development of higher psychological processes (pp. 79-91). Cambridge, MA: Harvard University Press.

Vygotsky, L. S. (1987). Genetic roots of thinking and speech. In R. W. Rieber \& A. S. Carton (Eds.), The collected works of L. S. Vygostky. Vol. 1: Problems of general psychology (pp. 101-120). New York, NY: Plenum. doi:10.1007/978-1-4613-1655-8_7

Wachs, H. (2001). Visual implications of Piaget's theory of cognitive development. Journal of Learning Disabilities, 14(10), 581-583. doi:10.1177/002221948101401007

Warner, M. C. (1999). The trouble with normal: Sex, politics and ethics of queer life. New York, NY: Free Press.

Warren, D. H. (1989). Implications of visual impairments for child development. In M. C. Wang, M. C. Reynolds, \& H. J. Walberg (Eds.), Handbook of special education: Research and practice. Vol. 3: Low-incidence conditions (pp. 155-172). Oxford, UK: Pergamon. 
Watson, J. (1924). Behaviorism. New York, NY: Norton.

Waxman, B. F. (1991). Hatred: The unacknowledged dimension in violence against disabled people. Sexuality and Disability, 9, 185-199. doi:10.1007/BF01102392

Wechsler, D. (1991). Wechsler intelligence scale children (3rd ed.). San Antonio, TX: The Psychological Corporation.

Whitney, C. R. (1993, January 19). Disabled Germans fear they'll be the next target. The New York Times, p. A3.

Wilder, D. (1987). Personal responsibility for illness. In D. Van De Veer \& T. Regan (Eds.). Health care ethics: An introduction (pp. 326-358). Philadelphia, PA: Temple University Press.

Wilkins, S., \& Cott, C. (1993). Aging, chronic illness and disability. In M. Nagler (Ed.), Perspectives on disability (2nd ed., pp. 363-377). Palo Alto, CA: Health Markets Research.

Wilson, E. O. (1998). Consilience: The unity of knowledge. New York, NY: Knopf.

Young, R., \& Olsen, E. (1991). Introduction. In R. Young \& E. Olson (Eds.), Health, illness, and disability in later life: Practice issues and interventions (pp. 1-7). Newbury Park, CA: Sage.

Zarit, S. H., \& Zarit, J. M. (1984). Psychological approaches to families of the elderly. In M. G. Eisenberg, L. C. Sutkin, \& M. A. Jansen (Eds.), Chronic illness and disability through the life span: Effects on self and the family (pp. 269-288). New York, NY: Springer Publishing Company.

Zigler, E., Piotrkowski, C. S., \& Collins, R. (1994). Health services in head start. Annual Review of Public Health, 15, 511-534. http://www.annualreviews.org/doi/pdf/10.1146/ annurev.pu.15.050194.002455

Zigler, E., \& Valentine, J. (Eds.). (1979). Project Head Start: A legacy of the war on poverty. New York, NY: Free Press.

Zola, I. K. (1983). Socio-medical inquiries: Recollections, reflections, and reconsiderations. Philadelphia, PA: Temple University Press.

Zola, I. K. (1985). Depictions of disability-metaphor, message, and media: A research and political agenda. The Social Science Journal, 22, 5-17.

Zweig, S. (1962). Wider horizons on Freud. In L. Gerard (Ed.), Sigmund Freud: The man and his theories. New York, NY: Fawcett. 